\title{
O VALOR DE USO DO IMPOSSÍVEL ${ }^{1}$
}

\author{
The use VAlue of the IMPOSSIBLE \\ Denis Hollier \\ Universidade de Nova York \\ Nova York, Estados Unidos
}

\section{Resumo}

Visando à reflexão sobre o projeto da revista Documents, publicada nos anos 1929-1930, o artigo discute as relaçôes entre a arte e a etnografia a partir da noção de "valor de uso", que se tornaria decisiva na obra de Georges Bataille. Para tanto, vale-se de textos publicados na revista por autores como Michel Leiris, Georges Henri Rivière e Carl Einstein, entre outros, além do próprio Bataille.

\section{Résumé}

Visant à la réflexion sur le projet de la revue Documents, publiée dans les années 1929-1930, l'article discute les rapports entre l'art et l'ethnographie à partir de la notion de "valeur d'usage", qui deviendrait décisive chez Georges Bataille. Pour ce faire, l'auteur se sert de textes publiés dans la revue par des auteurs comme Michel Leiris, Georges Henri Rivière et Carl Einstein, entre autres, outre Bataille lui-même.

\section{Abstract}

The purpose of this article is to reflect upon the art magazine Documents' project, published in the years 1929-1930. It discusses the relationship between art and ethnography from the standpoint of the notion of "use value", which would become decisive in Georges Bataille's work. To this effect, the author puts to use texts by authors such as Michel Leiris, Georges Henri Rivière and Carl Einstein texts, among others, as well as Bataille himself.

A beleza será irrecuperável ou não será.
Palavras-chave: Georges Bataille; revista Documents; etnografia; valor de uso.

Mots-clés: Georges Bataille; revue Documents; ethnographie; valeur d'usage.

Keywords: Georges Bataille; magazine Documents; ethnography; use value.

\section{Documentos}

A aventura de Documentos (dois anos, quinze números) começa muito longe da vanguarda, no Gabinete das Medalhas, onde Bataille e d'Espezel são colegas, d'Espezel sendo, aliás, dire-

\footnotetext{
${ }^{1}$ Este texto foi publicado como prefácio da reimpressão de Documents, organizada pelo próprio Denis Hollier. Paris: Jean-Michel Place, 1991. Depois foi republicado em Les Dépossédés: Bataille, Caillois, Leiris, Malraux, Sartre. Paris: Minuit, 1993.
} 
* (BABELON, Jean. "Numismatique". In: L'Histoire et ses méthodes, ed. Charles Saraman. Paris: Gallimard, 1961: 329.)

tor de algumas revistas muito oficiais e mais para especializadas: Aréthuse, onde foram publicados os primeiros artigos de Bataille (então numismata), os Cahiers de la république des lettres, cujo número especial sobre "A América antes de Cristovão Colombo" em 1928 publica "A América desaparecida", seu primeiro grande artigo. D’Espezel, que está um pouco em toda parte, está também na Gazette des beaux-arts, financiada por Georges Wildenstein. Ele servirá de intermediário. Wildenstein financiará Documentos.

A numismática, segundo a definição que dela dará mais tarde Jean Babelon, um dos colaboradores de Documentos, é a ciência das "moedas que só têm cotação nas especulações de eruditos". ${ }^{2 *}$ Ela incluía também as medalhas, moedas que nunca tiveram cotação. A paixão do numismata tem algo da avareza. Ele ama o dinheiro, mas para guardá-lo e olhá-lo, como Harpagão. Não gosta de gastá -lo. Estranho amor desinteressado pelo dinheiro, amor por aquilo que tudo permite uma vez separado daquilo que permite, amor pelo dinheiro congelado, interdito, ao mesmo tempo exposto e em reserva. Ele tem a paixão dos que trocam, mas que são introcáveis. Dos condutores do valor de troca, ele exige que eles mesmos estejam fora de uso. A moeda deixa a Bolsa para reciclar-se, na rue de Richelieu, na Biblioteca Nacional. ${ }^{3}$

\section{Do documento segundo Chartes ${ }^{4}$}

Foi Bataille quem propôs o título da revista.

Parece que esse título, para os fundadores (Bataille, d'Espezel, Wildenstein), tinha valor de programa, quase de contrato. Mas, na

\footnotetext{
${ }^{2}$ Jean Babelon, também do Gabinete das Medalhas, figurava no comitê de redação de Documentos e colaborou na revista.

${ }^{3}$ Parece que, entre os membros da Escola de Chartes, a opinião geral, por volta de 1929, ainda prometia uma bela carreira de numismata a Bataille. René Grousset, por exemplo, em um artigo de Documentos, refere-se com consideraçáo aos "estudos de numismática do Sr. G. Bataille" (GROUSSET, René. "Un cas de régression vers les arts barbares". Documents, 1930, n. 2: 73).

Sobre a numismática de Bataille, cf. HOLLIER, Denis. La prise de la Concorde. Essais sur Georges Bataille. Paris: Gallimard, 1974: 227-228.

${ }^{4}$ A École Nationale des Chartes, fundada em 1821, dedica-se à formação de arquivistas e paleógrafos, i.e., à reconstituição de manuscritos antigos, ao estabelecimento de textos e imagens medievais, e ao tratamento de fotografias antigas, segundo uma definição de patrimônio histórico. Bataille foi "chartista", como são denominados os alunos da École des Chartes, de 1918, quando abandonou o seminário de Saint-Fleur, até 1922. Sua tese de conclusão de curso foi a edição crítica do manuscrito medieval Ordre de chevalerie. (N. dos T.)
} 
opinião de d'Espezel e Wildenstein, antes mesmo de a revista ter verdadeiramente começado, Bataille - que, com o título de "secretário geral", a dirigirá de fato - tinha deixado de respeitá-lo. ${ }^{5}$ A partir de 1929 (apenas um número da revista havia sido publicado), d'Espezel envia a Bataille uma nota mordaz e ameaçadora.

O título que você escolheu para essa revista é justificado apenas pelo que ele nos fornece de 'Documentos' sobre seu estado de espírito. É muito, mas não é realmente o suficiente. É preciso verdadeiramente retornar ao espírito que nos inspirou o primeiro projeto dessa revista, quando você e eu falamos dela com o Sr. Wildenstein. ${ }^{6}$

Encontrava-se a palavra "documento" na apresentação feita por Bataille de "A ordem da cavalaria", sua tese para a Escola de Chartes. O único valor desse texto medieval, diz ele, é documental. "O poema, sem valor literário, sem originalidade, tem como único interesse ser um documento antigo e curioso sobre as ideias cavalheirescas e sobre os ritos da investidura". ${ }^{7 *} \mathrm{O}$ contrato era, em conformidade com a concepção "chartista" do documento, publicar em Documentos apenas textos sem valor literário nem originalidade? Se é esse o caso; compreende-se que Espezel tenha ficado inquieto: pois Bataille publicou em Documentos seus próprios textos, os de Leiris e de alguns outros a que não faltam, sem sequer entrar no mérito de suas qualidades literárias, d'Espezel o sentiu, uma certa originalidade.

\section{Etnografia}

Dentre as rubricas enumeradas no subtítulo da revista, a trindade "Arqueologia Belas-Artes Etnografia” ocupa a posição central. ${ }^{8}$

\footnotetext{
${ }^{5}$ Lembranças de Documentos publicadas em: BATAILLE, Georges. Oeuvres complètes. Francis Marmande (Ed.), v. XI. Paris: Gallimard, 1988: 572.

${ }^{6}$ Um dos raros ecos suscitados pela revista, uma nota publicada nas Nouvelles littéraires, permitiu-se um jogo de palavras do mesmo gênero, fácil e sem maldade, sobre o título: "Documentos oferece em seu quarto número 'documentos' fotográficos bastante curiosos”.

${ }^{7}$ Ver também a resenha (publicada em Aréthuse em 1926) de um volume de numismática: "Esses documentos", escreve Bataille, "frequentemente tâo interessantes do ponto de vista arqueológico quanto do ponto de vista artístico, póem em relevo o esforço realizado antigamente para organizar uma magnífica rede de circulação" (BATAILLE, Georges. "L'ordre de chevalerie" (1922). Oeuvres complètes, vol. 1. Paris: Gallimard, 1970: 107.).

${ }^{8}$ Nos três primeiros números: "Doutrinas Arqueologia Belas-Artes Etnografia”. A partir do número 4: "Arqueologia Belas-Artes Etnografia Variedades".
}

(BATAILLE, Georges. "L'ordre de chevalerie" (1922). Oeuvres complètes, vol. 1. Paris: Gallimard, 1970: 100.) 
* (LEIRIS, Michel. "Revue des publications. Jean Brunhes, Races, documents commentés par Mariel Jean-Brunhes Delamare [etc.]". In: Documents, 1930, n. 6: 375.$)$

* (EINSTEIN, Carl. “À propos de l'exposition de la Galeria Pigalle". In: Documents, 1930, n. 2: 104.)
Cada uma remete a um domínio independente: a etnografia escapa geograficamente e a arqueologia historicamente à tutela das belas-artes. Mas essa relativização dos valores estéticos ocidentais agrava-se com uma relativização ainda mais radical, a dos valores estéticos enquanto tais. É ela que marca a escolha do termo "etnografia” em detrimento da expressão "artes primitivas". Ele tem valor de manifesto: estampa que Documentos não é outra Gazette des beaux-arts, e sobretudo uma Gazette des beaux-arts primitifs.

Documentos terá por plataforma uma oposição ao ponto de vista estético. ${ }^{9}$ Essa oposição está implicada no próprio título. Um documento é, em sua definição mesma, um objeto destituído de valor artístico. Destituído ou despojado, conforme tenha ou jamais tenha tido valor artístico. Mas de duas coisas uma: ou bem estamos lidando com documentos etnográficos, ou bem com obras de arte. Essa oposição binária (que dá ao termo "documento", mesmo isoladamente empregado, suas conotaçôes antiestéticas) não é uma audácia lexical. É inocentemente, sem dar a impressão de que está citando ou brincando com a palavra, que Leiris recorre a ela, nas páginas de Documentos, ao falar de uma obra de fotografias. "Faltava ainda na França", escreve ele, "um livro que apresentasse ao grande público uma coletânea de documentos puramente etnográficos e não simplesmente uma série de obras de arte".*

Carl Einstein, sem utilizar a própria palavra "documento", retoma a mesma oposição na resenha que faz de uma das mais importantes exposiçôes de arte primitiva da época, a exposição de arte africana e oceânica organizada por Tristan Tzara e Charles Ratton na Galeria do Teatro Pigalle: "É preciso tratar esta arte historicamente, e não mais apenas considerá-la unicamente do ponto de vista do gosto e da estética". ${ }^{10 *}$

${ }^{9} \mathrm{O}$ único colaborador de Documentos a defender a arte enquanto tal será um obscuro especialista em pré-história, Henri Martin: a propósito de esculturas pré-históricas, ele conclui que elas respondem a uma intenção que não é unicamente "cultual ou simbólica". É preciso também levar em conta o "desejo imperioso de satisfazer a uma paixão: a da Arte." (MARTIN, Henri. "L'Art solutréen dans la valée du Roc (Charente)". In: Documents, nov. 1929, n. 6: 309). ${ }^{10}$ Teremos uma ideia do que a referência à etnografia tinha de polêmico, quando se falava de artes primitivas, se lermos a resenha da mesma exposição publicada em Formes. Ela concluía com esta declaração antietnográfica (deixo ao leitor o cuidado de pôr os sic onde quiser): "Após uma exposição como esta de que acabamos de falar, ninguém poderá classificar a arte negra e a arte oceânica, essas expressóes de duas civilizaçóes pouco conhecidas, dentre as curiosidades etnográficas" (A. S., em Formes). 
A modernidade faz um esforço incessante para superar a troca.*

$\mathrm{O}$ interesse perverso da numismática pelos sequazes do valor de troca não deixará um traço profundo em Documentos. O valor de uso tomará imediatamente a dianteira: ele constitui o eixo da reflexão dos etnógrafos, agrupados em torno de Georges Henri Rivière, o vice-diretor do Museu de Etnografia de Trocadéro. ${ }^{11}$ Mas não é apenas em relação aos valores em si que etnógrafos e numismatas se opõem. Eles se opõem também em relação à atitude a ser adotada diante do suporte objetivo (seria preciso dizer objetal): os etnógrafos resistem à exemplificação estética das ferramentas, enquanto os numismatas subscrevem à das moedas fora de uso. As vitrines que redouram o brasão das moedas depreciadas depreciam as ferramentas desativadas.

O nome de Marx não é mencionado uma única vez em Documentos. Mas a reflexão sobre o museu que os etnólogos desenvolvem segue bem de perto a oposição entre valor de uso e valor de troca que Marx desenvolve, na abertura de $O$ capital, no momento da análise da mercadoria. É também essa crítica da mercadoria que servirá de moldura à efêmera frente comum de etnólogos e surrealistas dissidentes que constituirá, durante sua frágil existência, a especificidade de Documentos. Uma parte importante da vanguarda dessa época, que é a época da resistência ao formalismo modernista dos anos 1920, é, com efeito, animada pelo desejo de um retorno, e até mesmo de uma regressão, ao que poderíamos chamar de primitivismo do valor de uso. E é em nome do valor de uso que cada uma dessas duas correntes critica, à sua maneira, a descontextualização formalista. ${ }^{12}$

\footnotetext{
${ }^{11}$ Vários colaboradores regulares são ou estão prestes a tornarem-se etnógrafos: Marcel Griaule, André Schaeffner, Michel Leiris. Entre os irregulares, notabilizase o nome de Maurice Leenhardt. Seria preciso acrescentar Claude Lévi-Strauss, já que é ele o autor do artigo assinado Paul Monet no número de homenagem a Picasso (Carta de Lévi-Strauss a Jean Jamin, julho de 1986).

${ }_{12}$ Nesse sentido, como Jean Jamin mostrou de maneira convincente, nunca houve, mesmo em Documentos, um projeto propriamente comum entre os etnógrafos e os surrealistas (ou, retomando a expressão excessivamente sedutora de James Clifford, nunca houve "etnografia surrealista"). Houve simplesmente, para citar o título de Métraux, encontros com os etnógrafos, e esses encontros tiveram por terreno uma certa resistência à descontextualização mercantil. $\mathrm{O}$ propósito do presente prefácio é situar o lugar desses encontros e demarcar seus limites. Cf. JAMIN,
}

* (BARTHES, Roland. Le plaisir du texte. Paris: Seuil, 1973: 40.) 
* (GRIAULE, Marcel. "Poterie". In: Documents, 1930, n. $4: 236$.)
Conhecemos a descrição que as primeiras páginas de $O$ capital fazem do valor de uso. "A utilidade de uma coisa", escreve Marx, "faz dessa coisa um valor de uso." Essa utilidade ou valor de uso da coisa não é separável de seu suporte material. Ela não tem nenhuma existência autônoma, independente. Mas é também uma propriedade da coisa que só se realiza no consumo, isto é, na destruição, da coisa: o valor de uso náo sobrevive ao uso; ele desaparece realizando-se. É, portanto, um valor que a coisa pode apenas perder. $\mathrm{O}$ valor de troca, em compensação, não é uma propriedade intrínseca, exclusiva, dos objetos que permite trocar: ele deve ser comum a ao menos dois dentre eles. Mas, sobretudo, é em favor de um retardo no consumo que o valor de troca se separa do objeto. É um valor de uso diferido. A mercadoria é um objeto cujo consumo foi adiado, um objeto posto de lado, literalmente posto fora de uso, para ser posto no mercado e trocado. O desvio que define o mercado vale também para o museu: os objetos entram ali apenas abstraídos do contexto de seu valor de uso. É esse desvio (a mais-valia estética - senão mercantil - do que é posto fora de uso) que será tematizado nas reflexóes sobre o museu empreendidas pelos etnógrafos de Documentos.

Um breve artigo de Marcel Griaule, "Cerâmica", constitui um bom exemplo desse recentramento da reflexão museográfica em torno do valor de uso. Griaule denuncia ali "os arqueólogos e os estetas" por seu formalismo: admiraremos, diz ele, "a forma da asa [de uma xícara], mas, acrescenta ele, evitaremos estudar a posição do homem que bebe". ${ }^{13 *}$ À força de ver apenas a forma dos objetos (isto é, à força de apenas ver os objetos), não vemos mais como nos servíamos deles, não vemos mais sequer que eles serviam. Levar em conta o valor de uso implica, em outros termos, estar no mesmo pé que o objeto. $\mathrm{O}$ espectador, em lugar de ser o homem

Jean. "L'etnographie mode d'inemploi. De quelques rapports de l'ethnologie avec le malaise dans la civilisation". In: Le mal et la douleur. Jacques Hainard e Roland Kaehr (Eds.). Neuchâtel: Musée d'etnographie, 1986.

${ }^{13} \mathrm{O}$ que é essencial em um objeto não é sua forma, mas seu uso. $\mathrm{O}$ modo de usar apenas excepcionalmente é uma consequência de sua forma. Essa crítica ao estetismo formalista é reencontrada em Paul Rivet: "A etnografia não deve contentarse com o estudo estritamente morfológico dos objetos fabricados pelo homem. Ela deve também, e eu diria de bom grado, ela deve sobretudo estudar as técnicas, que duram mais do que as formas e podem mais facilmente ser tomadas por empréstimo" (RIVET, Paul. "L'étude des civilisations matérielles: ethnographie, archéologie, préhistoire”. In: Documents, jun. 1929, n. 3: 132). 
que olha um vaso, deve entrar no espaço do objeto e colocar-se na posição do homem que bebe.

Mas é no artigo de André Schaeffner sobre os instrumentos musicais ("Instrumentos musicais em um museu etnográfico") que encontramos a crítica mais desenvolvida de uma museografia em que a exposição requer que se retire de uso, por descontextualização, os objetos expostos. Griaule exigia do museu evocado por ele, ao lado do vaso, o fantasma do homem que bebe. Para Schaeffner, um instrumento musical isolado é uma abstração. Ele precisa ser acompanhado. Documentos fotográficos e fonográficos devem lhe permitir retornar ao concreto: a posiçáo do instrumentista que o toca, o som ou os sons que produz etc. ${ }^{14}$ Mas há toda uma gama de performances que se desenrolam sem outro instrumento além do corpo (mortal) do músico, e que consistem em gestos que, diz Schaeffner, "seriam aniquilados se a fotografia não lhes conservasse o procedimento".* O valor de uso, segundo Marx, remete sempre em última análise aos órgãos e às necessidades de um corpo vivo. É, portanto, normal que, de acordo com essa lógica, a insistência no valor de uso dos objetos expostos (em sua função, e não unicamente em sua forma) conduza à introdução do corpo no espaço do museu (ela abre o espaço do museu ao mundo do corpo e das necessidades). O conceito central dessa museologia é o de técnicas do corpo.

Há um contrato simbólico em torno da beleza: da mesma forma que não falamos de dinheiro à mesa, devemos nos calar no museu sobre as origens laboriosas dos objetos expostos. Como o dinheiro, a beleza não tem cheiro. Passa-se a esponja. Assim o exige o arrivismo estético. Nenhum amador perguntará por que eles nunca tinham sido vistos antes de serem expostos.

Os etnógrafos de Documentos se batem contra esse contrato e contra o recalque do valor de uso implicado por ele. Querem um museu que não reduzisse automaticamente os objetos a suas propriedades formais, estéticas, um espaço de exposição de onde o valor

\footnotetext{
14 "Ao lado do instrumento exposto deve figurar uma fotografia de seu instrumentista; o objeto mudo, e sua posição entre as mãos de quem o desperta e de repente o multiplica" (SCHAEFFNER, André. "Des instruments de musique dans un musée d'ethnographie". In: Documents, out. 1929, n. 5: 252).

Posição próxima da de Georges Duhuit, que, na mesma época - por exemplo em seu artigo dos Cahiers d'art sobre os tecidos coptas ("Tissus coptes", 1927) opunha-se à reificaçáo museográfica dos objetos cerimoniais.
}

* (SCHAEFFNER, André. "Des instruments de musique dans un musée d'ethnographie". In: Documents, out. 1929, n. 5:254.) 
* (LEIRIS, Michel de. “Du musée d'Etnographie au Musée de l'Homme". In: La nouvelle revue française, ago. 1938, n. 299: 344.)

\footnotetext{
* (DA VINCl, Leonardo apud BENJAMIN, Walter. "L'oeuvre d'art au temps de ses techniques de reproduction". In: Oeuvres choisies. Traduzida por Maurice de Gandillac. Paris: Julliard, 1959: 233.)
}

de uso não fosse excluído, no qual ele pudesse ser não simplesmente representado, mas exposto, manifestado. Eles queriam desmontar a alternativa que quer que nos sirvamos de uma ferramenta e que olhemos um quadro. Que a entrada de uma ferramenta no museu não tivesse por condição a negação de suas próprias origens. Em lugar de substituí-la por um valor de troca ou de exposição, esse espaço preservaria o valor de uso, permitiria que ele sobrevivesse à descontextualização, apartado de seu fim, mas ainda valor de uso, um valor de uso de sabático. Ao mesmo tempo útil e ocioso. É a utopia de um espaço em que seria possível, como dizem os americanos, ter o bolo e comê-lo. Não são os sapatos de domingo, são os sapatos de todos os dias, mas no dia de descanso. As roupas de trabalho no dia de descanso. ${ }^{15}$

Em 1937, sete anos após o fim de Documentos, o Museu de Trocadéro foi destruído, substituído pelo Palácio de Chaillot. Em suas novas instalaçôes, o Museu de Etnografia, no ano seguinte, torna-se o Museu do Homem. Leiris apresenta, na Nouvelle Revue Française, as ambiçóes dessa instituição. O termo "documento" aparece várias vezes nesse breve artigo. "Como proceder para que os documentos (observaçôes, objetos de coleções, fotografias), cujo valor está ligado ao fato de serem coisas colhidas in loco, possam guardar um frescor qualquer, uma vez consignados nos livros ou engaiolados nas vitrines?" E continua: "Toda uma técnica da apresentação deverá intervir como sequência à técnica da coleta, se quisermos que os documentos não se tornem simples materiais para uma cansativa erudição".*

\section{No local}

A superioridade da pintura sobre a música está ligada ao fato de que, desde o momento em que aquela é chamada a viver, não há mais razão para que morra, como é o caso, ao contrário, da pobre música... A música se evapora assim que tocada, perenizada pelo uso do verniz, a pintura subsiste.*

\footnotetext{
${ }^{15}$ Essa reflexão sobre o que seria um museu do valor de uso não é destituída de relação com a que Heidegger vai desenvolver alguns anos mais tarde (1935), em "A origem da obra de arte", a propósito dos quadros de Van Gogh representando sapatos. É o "ser-produto do produto que chega, somente pela obra e somente na obra, ao seu aparecer" (HEIDEGGER, Martin. "L'origine de l'oeuvre d'art". In: Chemins qui ne mènent nulle part. Trad. Wolfang Brokmeier. Paris: Gallimard, 1966: 27).
} 
Não é inteiramente um acaso se é a propósito do jazz que Sartre, retornando de Nova York, formulou pela primeira vez seu imperativo estético: as obras do espírito, como as bananas, devem ser consumidas no local. As artes primitivas (de que o jazz faz parte) são, com efeito, submetidas, ou melhor se submetem, ao que Proust chamava a tirania do Particular. Elas não obedecem às leis do mercado, reconhecem apenas o valor de uso, mas é também o que lhes permite fazer suas exigências. Estas estão todas ligadas ao fato de que as artes não se deslocam. Não se pode contar com elas para dar o primeiro passo. Esses objetos intransportáveis, inseridos no tecido social de uma maneira táo estreita que não sobreviveriam à extração, impóem a lei do "local", on the spot.

É a propósito da igreja de Balbec que Proust evoca essa tirania do Particular: como Balbec é "o único lugar do mundo que possui a igreja de Balbec”, essa igreja, como as bananas de Sartre, só entrega seu gosto no local.* O narrador de Em busca do tempo perdido faz essa observação diante da igreja. Mas ao mesmo tempo pensa nos moldes daquelas estátuas que viu no Museu de Trocadéro. Ao lado do Museu de Etnografia, o Trocadéro da III ${ }^{a}$ República abrigava com efeito este outro convite à viagem, mesmo que se trate de uma viagem menos distante, o Museu dos Monumentos Franceses. Sem fazer de Proust um etnógrafo, a conjunção é significativa. Mais de uma partida teve que ser decidida durante uma visita a um dos dois museus abrigados nesse edifício hoje desaparecido, e do qual todos diziam que a coisa sem seu lugar não é nunca a própria coisa. Essas duas instituiçôes, cuja contiguidade é sem dúvida acidental, expóem o mesmo desenraizamento, a mesma nostalgia de obelisco ("os coqueiros ausentes da soberba África”). Sua resistência dupla e comum às leis do valor de troca e de exposiçâo leva a etnografia e a reflexão estética a uma mesma exigência de insubstituível, à mesma nostalgia de um mundo submetido à tirania do valor de uso. O "particular", com efeito, remete aqui à heterogeneidade introcável de um real, a um intratável núcleo de resistência à transposição, à substituição, a um real irredutível à metáfora.

A mesma articulaçấo da tirania do particular e do valor de uso está no cerne de umas das mais importantes reflexôes da época sobre o estatuto da obra de arte no contexto de sua mercantilização, o ensaio de Walter Benjamin, "A obra de arte na época de sua reprodução técnica”, publicado em 1936. Benjamin descreve ali em termos de valor de uso o valor que uma obra de arte recebe em

* (PROUST, Marcel. À l'ombre des jeunes filles en fleurs. Paris: Gallimard, 1988 [Folio n. 1946]: 228.) 
* (BENJAMIN, Walter. "L'oeuvre d'art au temps de ses techniques de reproduction". In: Oeuvres choisies. Traduzida por Maurice de Gandillac. Paris: Julliard, 1959: 203.) razão de sua unicidade: ser única é precisamente ter apenas valor de uso, não ter nenhum valor de troca, ter seu valor investido em sua introcabilidade. "O valor de unicidade próprio à obra de arte 'autêntica'", escreve ele, "funda-se sobre o ritual no qual residia inicialmente seu valor de uso". Ou ainda: "A unicidade da obra de arte não se distingue de sua integração neste conjunto de relaçóes que nomeamos tradição".* A referência à tradição indica a natureza ritual e cultual (em vez de econômica e instrumental) do valor de uso aqui invocado. Para dizê-lo de outra maneira, a obra de arte é única apenas porque não é separável de seu contexto, porque se deixa consumir apenas no local. Sua originalidade também havia sido atingida pelo museu bem antes que a fotografia a tivesse ameaçado (como Duthuit o mostrou, o museu não esperou Malraux para ser imaginário). Antes da questão de sua reprodutibilidade, há a de seu deslocamento. As depreciaçóes atribuíveis à reprodução mecânica eram, senão presentes, ao menos já programadas, em sua descontextualização museográfica. (De onde se conclui, aliás, que, em todo rigor, não é em um museu que encontraríamos um original no sentido benjaminiano do termo: a aura, com efeito, ligase menos ao próprio objeto original que a sua articulação cultual a um lugar e a um momento). A aura da obra de arte remete ao seu valor de uso: e Benjamin pode escrever que "o valor de uso da arte como objeto cultual" opóe-se diretamente ao "seu valor como realidade passível de exposição".*

A tripla conjunção do valor de uso, do ritual, e da unicidade do lugar, que é a forma que a tirania do particular toma em Benjamin, purga o conceito de valor de uso de qualquer conotação utilitarista. Em seu ensaio, Benjamin não analisa a gênese da obra de arte a partir da desativação das usinas, mas a partir da das igrejas. Sua referência ao valor de uso não implica tampouco nenhum juízo sobre a utensilidade de um objeto ou a utilidade de uma técnica. Essa referência implica simplesmente o seguinte: a coisa só tem lugar no local. Ela não se deixa nem transpor nem transportar. Ela resiste à reprodução e ao deslocamento. À metamorfose dos deuses. O valor de uso (ritual, cultual) situa-se além da utilidade (ele não remete ao lucro, mas à despesa). É o que é nomeado pela tirania do particular: uma dependência absoluta com relação a objetos ciumentos, insubstituíveis. Em última instância, o valor de uso descreve a dependência ansiosa daquele que não pode mudar de objeto, que se consome no local, na impossibilidade de privar- 
se dele. Em Proust, diante da igreja de Balbec, é a insubstituível Albertine que o exercerá.

Em Documentos, a nostalgia do valor de uso segue duas inclinações diferentes. Para os etnólogos, ela segue uma inclinação profana e o valor de uso remete para eles à utilização técnica, social, econômica do objeto (é de vasos que fala Griaule, e o homem que se serve deles não é necessariamente um sacerdote). Mas não é nesse tipo de produção material que Leiris pensa quando censura o esteticismo museográfico por transformar "uma máscara ou uma estátua, construída visando a fins rituais precisos e complicados, em um vulgar objeto de arte". Como em Proust e em Benjamin, o valor de uso aqui segue uma inclinação do sagrado: o uso remete à categoria que será explorada por Bataille com o nome de uso improdutivo. E é em torno dessas duas versóes, uma profana e a outra sagrada, do valor de uso que as duas tendências do comitê de Documentos, a etnografia e a vanguarda, vão divergir.

Aliás, a crítica mais forte do valor de troca utilitário publicada por Documentos não vem de um etnógrafo, mas de Bataille. Seu alvo é a comercialização da vanguarda que Bataille vê começar, curiosamente, em 1928 (uma referência à publicação de O Surrealismo e a pintura?), data em que as produçóes da vanguarda perderam todo o valor de uso para entrar na bolsa de valores da troca. Antes dessa data, a vanguarda se gastava, agora ela se compra. Ela respondia a obsessóes inconfessáveis, não transpostas, agora ela se pendura nas vitrines ("entra-se na galeria do marchand como na farmácia, em busca de remédios bem apresentados para doenças confessáveis"). Ela que dispensava "imagens que formam ou deformam desejos reais” agora não é mais que um período, o mais brilhante, se quisermos, mas nada mais que um período da história da arte. "Eu desafio qualquer amador de pintura", escreve Bataille, "a amar um quadro tanto quanto um fetichista ama um sapato". ${ }^{16 *}$ Pois a oposição não é entre ciência e amadorismo, mas entre amadorismo e fetichismo, entre a distância do amador e a obsessão do obcecado. Desafio um amador de arte moderna a consumir-se por uma tela como faz um fetichista por um sapato. ${ }^{17}$

\footnotetext{
${ }^{16}$ Em uma variante manuscrita do artigo, Bataille opôe "obsessão" e "assombração" ao "esteticismo dos amadores" (BATAILLE, Georges. Oeuvres complètes, v. 1: 656.)

${ }^{17}$ É a época em que Bataille trabalha em "O valor de uso de D.A.F. de Sade", onde denuncia (para retomar a expressão de Jasmin) o "modo de desuso" a que a admiração dos homens de letras reduziu a obra de Sade; o valor de uso de Sade
}

* (LEIRIS, Michel de. "Civilisation". In: Documents, set. 1929, n. 4: 221-222.) 
* (BATAILLE, Georges. "Van Gogh Prométhée" (1937). In: Oeuvres complètes, v. 1:500.)

* (RIVIÈRE, Georges Henri. "Le musée d'ethnographie du Trocadéro". In: Documents, abr. 1929, n. 1: 58.)

* (RIVET, Paul. "L'étude des civilisations matérielles: ethnographie, archéologie, préhistoire". In: Documents, jun. 1929, n. 3: 132.)
O exemplo escolhido por Bataille, embora clássico, é interessante. Esse sapato permite, com efeito, sublinhar o desvio que se desenha entre as duas versóes do valor de uso, a de Bataille e a dos etnógrafos. Pois o sapato é efetivamente um objeto útil, um objeto que serve (ele serve para andar etc.). Mas não é para andar que o fetichista "usa" o sapato. Ele tem para o fetichista um valor de uso que começa paradoxalmente (é precisamente o que Bataille chama em outro texto o "paradoxo da utilidade absoluta") no momento exato em que para de andar, no momento em que náo serve mais para andar. É o valor de uso de um sapato fora de uso. Lembremos que é a propósito dos sapatos pintados por Van Gogh que Heidegger havia confiado à obra de arte o cuidado de revelar o "ser-produto". ${ }^{18}$ $\mathrm{O}$ valor de uso dos sapatos desatados no interior do quadro. Mas o fetichismo de Bataille jamais será suficientemente desatado em relação a esse sapato para tirar proveito da pintura; ele quer, sem recolocá-lo em marcha, subtrair o sapato à ociosidade do quadro. O Van Gogh de Bataille não é tampouco o de Heidegger. Não é o dos sapatos sem sujeito, dos sapatos desatados pela pintura, mas o de um outro desate, da catacrese sacrificial tomada que o toma do corpo próprio, do desate da orelha que o mantém preso ao corpo. Uma orelha atribuível àquele que a escarra para além das expectativas do mercado gritando: este é meu corpo introcável. Uma orelha desviada do mercado de troca. O Van Gogh de Bataille recusava o espírito de transposiçóes: "não é à história da arte que pertence Vincent Van Gogh”**

\section{Nem alto nem baixo}

A questão do documento antropológico (sua coleta, sua conservação) ocupa um lugar central nos sumários de Documentos. A revista, aliás, segue atentamente a realocação do Museu Etnográfico, empreendida por Georges Henri Rivière, sob a direção de Paul Rivet, seu diretor desde 1927. No primeiro número, Rivière resume os trabalhos.* Dois meses mais tarde, é o próprio Rivet quem formula a ideologia que preside a essa reorganizaçáo.*

não deve limitar-se ao gozo bibliofílico dos amadores e conhecedores. BATAILLE, Georges. "La valeur d'usage de D.A.F. de Sade". In: Oeuvres complètes, v. 2. Ver também BATAILLE, Georges. Le Bleu du ciel. In: Oeuvres complètes, v. 3: 428.

${ }^{18}$ Para o lugar reservado ao fetichismo nessas análises de Heidegger, cf. DERRIDA, Jacques. "Restitutions". In: La vérité en peinture. Paris: Flammarion, 1978: 379 et seq. 
Essa ideologia, como já afirmei, é fundamentalmente antiestética. O Museu de Trocadéro não será um Museu de Belas-Artes assim como Documentos não será uma Gazette des beaux-arts. Nem por um instante Rivière planeja fazer concorrência ao Louvre. Ele felicita, ao contrário, Rivet por haver colocado o Museu de Trocadéro sob a tutela do Museu Nacional de História Natural, associando-o "a um dos primeiros corpos científicos da Nação, ao mesmo tempo em que permanece fiel a seu objeto: a etnografia”. Note-se, uma vez mais, que Rivière não fala de artes primitivas, mas de etnografia. Ele fala até mesmo em proteger a etnografia contra a moda de que as artes primitivas se beneficiam na vanguarda.

$\mathrm{Na}$ esteira de nossos últimos poetas, artistas e músicos, a indulgência das elites se dirige para a arte dos povos reputados primitivos e selvagens. [...] Isso provoca na etnografia estranhas incursōes, aumenta uma confusão que se acreditava reduzir. [...] O Trocadéro renovado podia fundar-se em um contrassenso, tornar-se um Museu de Belas-Artes em que os objetos se repartiriam sob a égide única da estética. Pobre princípio na verdade, que não leva senão a afastar do quadro, e ao acaso, apenas alguns de seus elementos essenciais. ${ }^{19 *}$

São, com efeito, os etnógrafos que formam a primeira fila da cruzada antiestética. ${ }^{20}$ Rivet:

${ }^{19}$ Etnografia e Belas-Artes ligam-se a instituições distintas. Do panorama das competências museográficas fornecido por Rivière, reteremos suas atribuiçóes respectivas: no Louvre, "as belas-artes e a arqueologia", no Museu de Trocadéro, "a Etnografia" etc.

Um museu de etnografia, precisa Rivière, deveria abraçar "em seu conjunto" as civilizaçóes "primitivas e arcaicas". Pois são as sociedades que constituem os conjuntos; elas são anteriores à separação das funções próprias às "sociedades mais evoluídas": para as sociedades primitivas, o mesmo estabelecimento servirá, portanto, ao mesmo tempo "como Museu de Belas-Artes, Museu do Folclore e Conservatório de Artes e Ofícios".

Não eram provavelmente os surrealistas que reivindicavam a entrada no Louvre das artes primitivas. Em 1930, depois da exposição da Galeria Pigalle, Paul Guillaume, deplorando o culto do exótico e do selvagem a que o surrealismo acabara levando a moda das artes primitivas, vai declarar a arte negra madura para o Louvre.

${ }^{20}$ Desnos exprime uma resistência idêntica no que toca a outra estetização, a de que se beneficia (ou sofre) a imagística popular: "são manifestações populares que padecem mais com essas vogas súbitas" (DESNOS, Rober. "Imagerie moderne”. In: Documents, dez. 1929, n. 7: 377). A mesma nota em Bataille: "estetas muito miseráveis, ao buscar situar sua admiração clorótica, inventam rasamente a beleza das usinas" (BATAILLE, Georges. "Chéminée d'usine". In: Documents, nov. 1929, n. 6: 329.)
* (RIVIÈRE, Georges Henri. "Le musée d'ethnographie du Trocadéro". In: Documents, abr. 1929, n. 1: 58.) 
* (RIVET, Paul. "L'étude des civilisations matérielles: ethnographie, archéologie, préhistoire". In: Documents, jun. 1929, n. 3: 133.)

* (GRIAULE, Marcel. "Un coup de fusil". In: Documents, 1930, n. 1: 46.)

* (SCHAEFFNER, André. "Des instruments de musique dans un musée d'ethnographie". In: Documents, out. 1929, n. 5: 252.)

* (CLIFFORD, James. "On Ethnographic Surrealism". In: Comparative Studies in Society and History, out. 1981: 52.) é capital que o etnógrafo, como o arqueólogo, como o especialista na pré-história, estude tudo o que constitui uma civilizaçáo, que ele não negligencie nenhum elemento, por mais insignificante ou banal que pareça. [...] Os coletores cometeram o erro de um homem que queria julgar a civilização francesa atual através dos objetos de luxo que encontramos apenas em um grupo muito limitado da populaçáo.*

Griaule: a etnografia deve "desconfiar do belo, que é bem frequentemente uma manifestaçâo rara, isto é, monstruosa, de uma civilização".* Schaeffner: "Nenhum objeto com fins sonoros ou musicais, por mais 'primitivo', por mais informe que pareça, nenhum instrumento musical será excluído de uma classificação metódica". * Da mesma forma que o psicanalista deve prestar a tudo uma atenção igual, assim também o coletor antropológico deve reter tudo. Nunca privilegiar um objeto por ele ser "belo", nunca excluir outro por ele parecer insignificante ou repugnante, ou informe.

"Nada será excluído", diz Schaeffner. "Nenhum objeto, por mais informe que seja".

No número de dezembro de 1929, Leiris e Griaule consagram, cada um, um breve artigo ao "escarro". Trata-se de um artigo etnográfico ou surrealista? São, segundo James Clifford, nos dois casos, artigos de etnografia surrealista. "O etnógrafo (como o surrealista) tem o direito de chocar". Clifford acrescenta: "Escarrar denota uma condição fundamentalmente sacrílega. Segundo essa definição revista e corrigida, falar ou pensar é também ejacular". ${ }^{21 *}$

Esta definição requer evidentemente que possa ser aplicada a si mesma. O artigo "escarro", fazendo o que diz, deve tornar-se ele próprio uma ejaculação sacrílega. É preciso que o etnólogo, quando fala de escarro, choque tanto quanto o faria escarrando. O que explica o recurso ao direito de chocar. Estamos também lidando aqui com um artigo (que se tome a palavra no sentido que se quiser) de um tipo sensivelmente diferente daqueles de que se tratou até o momento.

Trinta anos mais tarde, após a morte de Bataille, é através dessa mudança de registro que Leiris caracterizará a curva traçada por Documentos. "O irritante e o heteróclito, se não o inquietante, tornaram-se, mais do que objetos de estudo, traços inerentes à pró-

21 "O etnógrafo, como o surrealista, tem licença para chocar".

A palavra "sacrílega" vem do artigo de Leiris, que escrevia: "O escarro é um cúmulo enquanto sacrilégio". (LEIRIS, Michel de. "Crachat". In: Documents, dez. 1929, n. 7: 382). 
pria publicação".* Deixa-se, com efeito, a coleta de documentos antropológicos por uma intervenção de tipo diferente. No próprio momento em que, em nome daquilo que náo é nem alto nem baixo, o saber pretendia apropriar-se do baixo, algo lhe acontece. Ele se suja com seu objeto. Deixa-se contaminar por ele. $\mathrm{O}$ objeto não se mantém à distância, perde a reserva, esquece-se sobre a página que fala dele. Digo uma flor - e ela acontece. As coisas ocorrem no próprio local onde são contadas. On the spot. O artigo "Metáfora" de Leiris instaura a mesma irrupção do referente: o objeto de estudo torna-se ali de alguma forma um traço da publicação, "esse próprio artigo, conclui ele, é metafórico”.* Ainda não é o chifre de um touro, mas algo que queria se apropriar da página a atinge, algo que não está em seu lugar, algo heterogêneo. Como a mosca sobre o nariz do orador. Ou como o eu no todo metafísico. A aparição do eu, diz Bataille, é perfeitamente chocante. É exatamente o que chocava d'Espezel. "O título que você escolheu para essa revista é justificado apenas pelo que ele nos oferece de 'Documentos' sobre seu estado de espírito".

\section{Licensed to shock}

Mas, precisamente, diz Clifford, o etnógrafo, como o surrealista, tem o direito de chocar.

Ele reconhece apenas um princípio. Mostrar tudo. Realçar tudo. Dizer tudo. Tudo está em seu lugar quando as coisas acontecem no museu. O Museu do homem será o Museu do todo do homem. Nibil humani alienum. Nenhum objeto, por mais informe que pareça, será excluído. Tudo o que é merece ser documentado. Há uma forma de compaixão, um movimento de caridade epistemológica, nessa tomada de partido pelas pequenas coisas. A ciência consola as realidades humildes do desprezo a elas dirigido pelo elitismo dos estetas. Clifford conclui disso que a etnografia "tem em comum com o surrealismo o abandono da distinção entre o alto e o baixo na cultura".* E do abandono dessa distinção decorreria que o baixo não choca mais.

D’Espezel não compartilha da mesma opiniáo. Ainda não tinha lido o artigo "Escarro".

Há algo de nietzschiano nesse projeto de dizer "sim" a tudo. De querer o que é em sua totalidade. De dizer sim, sem escolher, àquilo que não escolhemos. De reafirmar, uma coisa após outra, a
* (LEIRIS, Michel de. "De Bataille l'impossible à l'impossible Documents". In: Brisée. Paris: Mercure de France, 1965: 261.)

* (LEIRIS, Michel de. "Métaphore". In: Documents, jun. 1929, n. 3: 170.)

* (CLIFFORD, James. "On Ethnographic Surrealism", op. cit.: 49 .) 
* (BATAILLE, Georges. "Informe". In: Documentos, dez. 1929, n. 7: 382.) totalidade do que é na vitrine ontológica de um museu sem reserva. Mas o eterno retorno de tudo tem um preço. Ninguém afirma o todo inocentemente.

No mesmo número do artigo "Escarro" de Griaule e Leiris, Bataille publica "Informe", que lhe faz eco, em particular, com seu teorema final: "dizer que o universo não se assemelha a nada e que ele é apenas informe equivale a dizer que o universo é algo como uma aranha ou um escarro".* Informe: é a mesma palavra de Schaeffner, mas sem a humildade que tinha sob a pena do etnógrafo. Ampliada, como o tédio baudelairiano, para dimensóes cósmicas, ela nomeia agora a monstruosidade inapresentável do todo. Não se trata mais de mostrar algo a que tudo, inclusive o informe, se assemelha; é o todo que, por ser informe, se encarrega de uma monstruosidade que não pode ser exposta. Ele não se assemelha a nada. É um todo sem exemplo. $\mathrm{O}$ informe (excessivamente presente para ser apresentável) não se deixa mais conter. Em mise en abyme, ele desestabiliza a diferença entre objeto e mundo, entre parte e todo. Mais uma vez, a frente comum da vanguarda e da etnografia se desfaz. As mesmas palavras não realizam em toda parte as mesmas tarefas. $\mathrm{O}$ valor de uso da palavra “informe” não é o mesmo quando é Schaeffner ou quando é Bataille ou Leiris que a utilizam. O que Schaeffner quer é classificar até mesmo o informe; ao passo que o informe, para Bataille, "desclassifica". De um lado, a lei do sem exceção, do outro, a de uma exceção absoluta, de um único sem propriedades.

\section{Licença de etnógrafo}

Clifford insiste na importância da lição de Mauss para Documentos. Mas o Mauss citado por ele não é o dos grandes textos (a dádiva, o sacrifício, as variações sazonais etc.), mas sim o autor da comunicação sobre as técnicas do corpo - posterior a Documentos: ela data de 1934 -, um texto que sob muitos aspectos recorta (sem abordá-los) os problemas de museografia tão importantes para Documentos.

O fato é, aliás, que, entre as técnicas do corpo mencionadas por Mauss, há a do escarro. Mas de um escarro que não sacrílego, é terapêutico (ele figura sob a rubrica dos cuidados da boca). A coisa pode, portanto, ser feita e dita da maneira mais apropriada possível. E, a propósito, se por acaso houver um erro a ser redimido, o 
etnógrafo está ali, pronto para pagar. Esse escarro pasteurizado dispensa Mauss de invocar o direito de chocar do etnólogo. ${ }^{22}$

Mas para Bataille e Leiris a higiene não desculpa nada. Ao contrário, ela é a cruz deles. A palavra "higiene", sob a pena dos dois, tem precisamente o impacto de um escarro. A sujeira é própria do homem, de onde se conclui que quanto menos uma coisa é limpa, mais ela é humana. E, inversamente, Leiris formula a equação com todas as letras. Falando do nu conforme era representando na pintura acadêmica, ele o declara "limpo e espoliado, e de certa maneira desumanizado".* A mesma equação é implicada pela fórmula em que Bataille declara que o dedão do pé é "a parte mais humana do

22 "Cuidados da boca - Técnica de tossir e de escarrar. Eis uma observação pessoal. Uma menininha não sabia escarrar e todas as suas gripes se agravavam por causa disso. Informei-me sobre isso. No vilarejo de seu pai e na família de seu pai particularmente, no Berry, não se sabe escarrar. Eu a ensinei a escarrar. Davalhe quatro centavos por escarro. Como ela desejava ter uma bicicleta, aprendeu a escarrar. Ela é a primeira da família a saber escarrar". (MAUSS, Marce. "Les techniques du corps". In: Anthropologie et sociologie. Paris: Presses Universitaires de France, 1960: 383). Esse artigo é em muitos anos posterior ao de Griaule e ao de Leiris.

Clifford não menciona essa referência ao escarro. Mas cita a seguinte rubrica: "Higiene das necessidades naturais - aqui poderia enumerar-lhes inúmeros fatos" (CLIFFORD, James. "On Ethnographic Surrealism”, op. cit.: 47). Mauss diz que poderia, mas não o faz. Pudor? O etnógrafo hesita em utilizar seu direito de chocar? Não se sente, como diz Clifford, licensed to shock?

É com os problemas colocados pela documentação museográfica das técnicas do corpo que Lévi-Strauss começa sua introdução à obra de Mauss (: XI-XIV): "Colecionamos os produtos da indústria humana", observa ele, mas não fazemos nada pelo corpo. Ele também sugere a constituição de "Arquivos internacionais das técnicas corporais". E fornece a título indicativo uma breve lista das ditas técnicas. A primeira mencionada concerne à "posição da mão na micçáo no homem", um gesto que está ligado a essa "higiene de necessidades naturais", sobre a qual Mauss poderia ter enumerado inúmeros fatos. Esse exemplo não é indiferente. Testemunha da proximidade entre tabu e valor de uso. E constitui nesse sentido o negativo antropológico daquilo que a Fonte de Marcel Duchamp foi para a vanguarda. No dia em que os museus das belas-artes e os museus de antropologia se fundirem, a não exibível posição da mão do homem na micção poderá enfim encontrar a inutilizável Fonte de Duchamp. À espera desse dia, eles continuam como cães de porcelana, tão separadas quanto Aquiles da tartaruga, solapando os valores de exposição.

Ver também as reflexões sobre os museus de antropologia no capítulo final de Antropologia estrutural, onde Lévi-Strauss examina o estatuto dos museus de antropologia: "não poderia tratar-se exclusivamente de coletar objetos" (LÉVISTRAUSS, Claude. Anthropologie structurale. Paris: Plon, 1958: 413); hoje, "os homens tendem a substituir os objetos" (Ibidem: 414).
* (LEIRIS, Michel de. "L'homme et son intérieur". In: Documents, 1930, n. 5: 261.) 
* (BATAILLE, Georges. "Le gros orteil". In: Documents, nov. 1929, n. 6: 297)

* (BATAILLE, Georges. "Les écarts de la nature". In: Documents, nov. 1930, n. 2: 79)

* (Ibidem: 82)

* (BATAILlE, Georges. "Figure humaine". In: Documents, nov. 1929, n. 4: 196) corpo humano": a mais humana, precisa ele, porque a mais suja, aquela que é submetida à "sujeira mais nojenta".*

Não se trata aqui, como com os etnógrafos, da reabilitaçáo dos humildes. Tudo se diz. Mas no tudo de Bataille algo de inconfessável permanece. Para dizê-lo é preciso expor um tabu, e, expondo-o, expor-se nele. $\mathrm{O}$ que induz uma despesa faz passar a comunicação do nível do valor de troca ao do valor de uso. Ou, para dizê-lo de outra forma, reintroduz o interdito na ciência. É preciso dizer tudo, sim, mas com a condição de que tudo não possa ser dito. $\mathrm{O}$ imperativo categórico é aqui atado a um torniquete em que o "você deve", assim que formulado, dá lugar a um: "portanto, você não pode". A vanguarda não quer o direito de chocar que lhe é oferecido pelos etnógrafos. Se alguém se formaliza, mostra-se o passe. Licença etnográfica? Mas o que seria um sacrilégio nos limites da simples razão?

\section{Desvios}

Griaule, Rivet e Schaeffner censuravam os estetas por sair da média. Ao selecionar o belo, eles privilegiavam o raro, portanto o monstruoso. A posição de Bataille é exatamente inversa. Em "Os desvios da natureza", a beleza encontra-se não mais do lado das exceções, mas do lado da norma estatística: "A beleza", escreve ele, "estaria à mercê de uma definição tão clássica quanto a da medida comum".* Assim, a teratologia (ciência dos desvios da natureza) é uma peça decisiva de sua estética. Mas essa teratologia implica que sejam invertidas as relaçóes entre o monstruoso e a feiura: enquanto os etnólogos se desviam da beleza por considerarem-na estatisticamente monstruosa, Bataille privilegia o monstruoso por julgá-lo esteticamente feio. Sua definição de monstruoso não é mais estatística, é estritamente estética. Se a privilegia, não é em razão de sua raridade. Ao contrário, longe de opô-la ao normal, ele faz dela o cerne da definição de individualidade (o impossível é cotidiano): tendo em vista o "caráter comum da incongruência pessoal e do monstro", o indivíduo é enquanto tal o lugar de todos os desvios.* Bataille se opóe à medida comum, não em nome de uma desmedida romântica, mas em nome de alguma coisa como uma desmedida bastante ordinária, uma ausência muito comum de medida comum. Em "Figura humana”, a própria espécie é descrita como uma “justaposição de monstros”.* Assim, é precisamente em torno 
do conceito de desvio que se desenha o maior desvio entre as duas tendências motrizes de Documentos, os etnógrafos e os antiestetas. Os etnógrafos querem o contínuo, Bataille quer a ruptura. Eles querem reconstituir os contextos para que tudo apareça em seu lugar, ao passo que ele encarrega o documento de expor a incongruência radical do concreto: de repente os seres mais ordinários não se assemelham com nada, deixam de estar em seu lugar. Perguntamo-nos quem é o responsável pela publicação em Documentos da "Crise da causalidade", em que Hans Reichenbach denuncia no determinismo uma "falsa idealização": "cada acontecimento é um lance de dados", acrescenta ele.*

Esse desvio (o hiatus irrationalis) é uma das peças decisivas da ideologia estética de Documentos. Com a pintura moderna, diz Carl Einstein, "colocamo-nos fora do normal. [...] Desviamo-nos da monotonia biológica". A rapidez da imaginação de Picasso "ultrapassa o conservadorismo biológico". ${ }^{23 *} \mathrm{~A}$ arte moderna começa no momento preciso em que as mesmas causas deixam de produzir os mesmos efeitos. Ela desmonta a reproduçáo do semelhante, o engendramento do mesmo pelo mesmo, a lei da homogeneidade biológico-estética. Em outras palavras, o belo é sempre o resultado de uma semelhança. Enquanto a feiura (como o informe) não se assemelha a nada. É sua definição. Seu espaço é o do aborto. Ela nunca consegue elevar-se ao estado do duplo, da imagem, da reprodução (do típico e do característico). Ela permanece um caso. Mas a estética de Documentos inverte os juízos de valor relativos a essas definições. É na falta da impossível cópia do feio que a beleza surge, uma beleza que nada mais é que o resultado ou o resíduo do fracasso da reprodução do feio. Para essa estética do desvio, que é, antes de mais nada, uma antiestética do intransponível (uma resistência à transposição estética), é secundário que o feio seja um fracasso da reprodução (não são os desvios da natureza que seriam fracassos da natureza), o essencial é que o próprio belo seja um fracasso da não reproduçáo. Uma reprodução que não tivesse chegado a fracassar até o final. Uma despesa que não tivesse tido lugar sem reserva. $\mathrm{O}$ valor de uso não teria sido totalmente consumido no local. $\mathrm{O}$ aborto de um aborto.

\footnotetext{
${ }^{23} \mathrm{Ou}$, a respeito dos quadros de Masson: "Estamos cansados da identidade biológica" (EINSENSTEIN, Carl. "André Masson, étude ethnologique". In: Documents, mai. 1929, n. 2: 102).
}

* (REICHENBACH, Hans. "Crise de la causalité". In: Documents, mai. 1929, n 2: 108.)

* (EISENSTEIN, Carl. "Pablo Picasso: quelques tabelaux de 1928". In: Documents, abr. 1929, n. 1:35.) 
* (BATAILLE, Georges. "X marks the spot". In: Documents, 1930, n. 7: 437.)
* (LEIRIS, Michel de. L'Âge d'homme. Paris: Gallimard, 1946: 17.)

\section{Documentos: eu não invento nada}

Há outro traço do documento. Ele restitui o real fac-similado, não metaforizado, não assimilado, não idealizado. Um documento, em outras palavras, não é inventado. Ele se distingue dos produtos da imaginação precisamente porque não é endógeno. Como os fatos sociais em Durkheim, o documento é transcendente. Eu não invento. Não tenho nenhuma influência. Ele ainda não foi assimilado pela metaforização estética. Heterogêneo e alógeno, ele é impactante, choca (tem uma força de choque) como o faria um trauma. $X$ marks the spot, para citar o título de um álbum de fotografias sensacionalista sobre a guerra das gangues de Chicago comentado por Bataille.*

Essa promoçáo do documento entra no quadro de uma condenação mais geral da imaginaçáo que faz parte da inspiração modernista. É a ela, por exemplo, que Leiris ligará seu projeto autobiográfico. Em "Da literatura considerada como uma tauromaquia", ele insiste sobre o fato de que $A$ idade do homem não é uma obra de ficção: é a "negação de um romance". Comparando sua autobiografia a uma espécie de colagem surrealista, ou melhor, de fotomontagem, ele a apresenta como uma coleção de provas: "nenhum elemento", diz ele, "foi utilizado aqui que não seja de uma veracidade rigorosa ou que não tenha valor de documento".* A mesma inspiração "documental" havia levado Bataille a acrescentar à História do olho um capítulo final de "Coincidências": essas lembranças permitem diminuir a parte tomada pela liberdade da imaginação na invenção romanesca. ${ }^{24}$

Nesse sentido, Documentos não é uma revista surrealista.

É uma revista agressivamente realista. ${ }^{25}$

${ }^{24}$ Bataille manifestará a mesma insistência, mais tarde, em "A tragédia de Gilles
de Rais". "Tais cenas não são obra de um autor. Elas aconteceram."
${ }^{25}$ As profissóes de fé realistas são numerosas. Por exemplo, de Leiris: "é, portanto,
em minha opinião cometer um contrassenso completo esquecer o caráter
fundamentalmente realista da obra de Picasso" (LEIRIS, Michel de. "Toiles
recentes de Picasso". In: Documents, 1930, n. 2: 62).
Ver também Georges Ribemont-Dessaignes: "Sou realista. [...] Há pessoas que
falam d'O-que-existe, e d'O-que-não-existe, e que só creem neste último negando-
lhe toda a existência. [...] Elas não passam de surrealistas". "Um pintor é sempre
um realista. Não conheço nenhum que não o seja. Pior para os surrealistas: que
eles abandonem toda relação com a pintura" (RIBEMONT-DESSAIGNES,
Georges. "Giorgio de Chirico". In: Documents, 1930, n. 6: 337-338).
E Desnos, em sua resenha de A Mulher 100 cabeças: "Para o poeta, não há 
"Apenas a imaginação dá conta para mim do que pode acontecer", escrevia Breton no Manifesto de 1924.* Mas Documentos não quer nem a imaginação nem o possível. A fotografia toma aí o lugar do sonho. E, se a metáfora é a figura mais ativa da transposição surrealista, o documento constitui sua figura antagônica, agressivamente antimetafórica. Com ele, o impossível, isto é, o real, expulsa o possível.

\section{De um materialismo fetichista}

Barthes terminava sua conferência sobre "O dedão do pé" descrevendo as palavras de Bataille "suficientemente recortadas, suficientemente brilhantes, triunfantes, para se fazerem amar, à maneira de fetiches".* Uma ouvinte intervém. Ela lamenta essa referência: falar de fetiche é diminuir o impacto dessas palavras. Barthes: "vejam, agora não se pode mais falar de fetichismo. É tarde demais para o fetichismo".

Efetivamente é tarde demais. O elogio irrestrito do fetichismo que encontramos em Documentos é sem dúvida o que mais nos distancia dele. Pois se, para a ouvinte de Barthes, o fetichismo evoca estratégias de evitamento de perversóes mais para soft, faceiras, medrosas, para Bataille ele define a exigência hard da própria coisa. O fetichismo é um realismo absoluto: ele póe em jogo desejos reais, em bairros reais, com objetos reais. Em nenhum momento Bataille opóe, como os marxistas, fetichismo e valor de uso (não há para ele fetichismo da mercadoria); quando invoca o fetichismo é, ao contrário, sempre contra a mercadoria. O fetiche é o objeto insubstituível, intransponível. "Desafio", escreve Bataille, "qualquer amador de pintura a amar uma tela tanto quanto um fetichista ama um sapato". ${ }^{26 *}$ E Leiris começa seu artigo sobre Giacometti opondo o fetichismo verdadeiro (fetichismo "não disfarçado") ao que ele chama de "fetichismo transposto" (ou mau fetichismo) das obras de arte: "Raramente, no domínio das obras de arte, encontramos alguns objetos (quadros ou esculturas) capazes de responder apro-

alucinação. Há o real" (DESNOS, Robert. "La femme 100 têtes, par Max Ernst". In: Documents, 1930, n. 6: 238).

${ }^{26}$ Portanto, esses ersatz que são aos olhos de Bataille as obras de arte são também tấo não desalojáveis quanto as catacreses. "Nada de realmente novo pode ainda substituí-las", escreve Bataille, a propósito desses insubstituíveis substitutos (BATAILLE, Georges. "L'esprit moderne et le jeu des transpositions". Documents, 1930, n. 8: 489).
* (BRETON, André. "Manifeste surréaliste". In: Oeuvres complètes, v.1. Marguerite Bonnet (Ed.) Paris: Gallimard, 1988: 312.)

* (BARTHES, Roland. "Les sorties du texte". In: Bataille. Paris: UGE, 1973: 62.)

* (BATAILlE, Georges. "L'esprit moderne et le jeu des transpositions". In: Documents, 1930, n. 8: 489.) 
* (LEIRIS, Michel de. "Alberto Giacometti". In: Documents, set. 1929, n. 4: 209.)

*(BERL, Emmanuel. Mort de la morale bourgeoise (1929). Paris: Jean-Jacques Pauvert, 1965: 174.) ximadamente às exigências desse verdadeiro fetichismo".* O fetiche transposto é precisamente aquele que foi posto fora de uso para entrar no mercado, aquele que foi degradado em mercadoria. Aquele de que não nos servimos, mas que colecionamos. Os objetos surrealistas de Giacometti seriam, segundo Leiris, os primeiros verdadeiros fetiches a reaparecer em muito tempo no ateliê de um artista parisiense. É significativo que, em Documentos, não sejam os etnógrafos que utilizem esse conceito que, no entanto, remete às religióes primitivas.

Em abril de 1929, Emmanuel Berl havia publicado seu panfleto Morte do pensamento burguês. Morte da morte burguesa deviria segui-lo alguns meses mais tarde. Bergson, Proust, os surrealistas, todo mundo está lá. A conclusão, intitulada "Defesa do materialismo", propóe um materialismo que merece a qualificação batailliana de baixo materialismo, um materialismo de uma baixeza agressiva que Berl apresenta como a arma proletária por excelência, a única arma de algum peso contra a burguesia. Esses termos lembram singularmente o artigo "Materialismo", publicado por Bataille alguns meses antes, no número de junho de 1929 de Documentos. Berl escreve que o materialismo "não consiste em dar um valor ontológico à matéria para recusá-lo a todo o resto, mas em procurar antes, na infinidade das causas que provocam um fenômeno, as causas mais simples e as causas mais baixas. [...] O materialismo", continua ele, "é, portanto, uma certa maneira de depreciar. Ele significa um certo gosto pela depreciação". ${ }^{27 *}$ Reconhecemos a definição de Bataille, que começa seu artigo com um ataque contra os materialistas que submeteram a própria matéria à exigência idealista do dever ser, a ponto de substituí-la por uma "forma ideal da

\footnotetext{
${ }^{27}$ Tendo como pano de fundo a crise do surrealismo, um breve diálogo se esboça entre Berl e Bataille. Em "Conformismos freudianos", Berl cita Bataille por ocasiáo de uma discussão do que ele chama de "fetichismo" contemporâneo. "O falo substitui entấo a folha da vinha. Nem mais nem menos. E para falar a linguagem de Georges Bataille, o idealismo que gangrena o fetiche faz dele um dever ser" (Formes, ${ }^{\circ} 5$, abril 1930).

A denúncia do dever ser inspira muitos sarcasmos antissurrealistas de Bataille: "Se dizemos que as flores são belas, é porque elas parecem conformes ao que deve ser." (BATAILLE, Georges. "Le langage des fleurs". In: Documents, 1930, n. 3: 162.); e "o espaço faria melhor, bem entendido, se fizesse seu dever de casa" (BATAILLE, Georges. "Espace". In: Documents, 1930, n. 1: 41.) Ao contrário, em Breton: "Cabe a nós opor-lhe em comum esta força invencível que é aquela do dever-ser, que é aquela do devir humano" (BRETON, André. "Position politique du surréalisme". In: Manifestes du surréalisme. Paris: Jean-Jacques Pauvert, 1962: 274).
} 
matéria, uma forma que se aproximaria mais do que qualquer outra daquilo que a matéria deveria ser". ${ }^{28 *}$

Mas apesar de diversos apelos a um populismo proletário, a inspiração desse materialismo é mais heraclitiana do que marxista. Segundo esse materialismo do valor de uso, a matéria é definida precisamente como o que não dura. ${ }^{29}$ Como todo valor de uso, ele se esgota no consumo. E não renasce das próprias cinzas. Esgotase no local, não sobrevive a si mesmo. Não deixa nenhum rastro. Sequer uma lembrança. O materialismo de Bataille é uma exaltação do não acumulativo (o que leva à perda), da diferença a fundo perdido, sem representantes, sem futuro e sem reserva, sem sequência, sem descendentes, sem dia seguinte. A matéria despende-se integralmente, sem resto, sem nada deixar atrás de si mesma, fantasma, herdeiro, duplo. Um clarão - e depois a noite.

Devemos a Henry Charles Puech, especialista nas religióes maniqueístas, um artigo inesperado no qual apresenta Piranèse como o "Arquiteto niilista", um artista assombrado por uma arquitetura do desastre, animado pela "impaciência de uma realização total, este desejo de levar tudo até o fim e de que a ruína seja ruína absolutamente, de que a plenitude faça explodir este gosto pelo nada que ordena todos os progressos e de que o homem termine sob um amontoado de pedras que não poderíamos dizer se é uma construção ou se são escombros. Os fins dessa vontade são terrivelmente ambíguos: ou a ruína a ser reproduzida a retém, ou então agarra nela o desejo vivo de completá-la ainda, de varrer tudo, de construir o universo onde o homem seria achincalhado". ${ }^{30 *}$

\section{Reimpressão}

A significação da reimpressão não é a mesma conforme se trate de um livro ou de um periódico. Reedita-se um romance porque ele está fazendo sucesso ou porque chegou o momento de redes-

\footnotetext{
${ }^{28}$ Bataille retornará a essa crítica do "materialismo ontológico" em "Le bas matérialisme et la gnose" (In: Documents, 1930, n. 1: 1).

29 "A matéria", escreve Berl, "é o que não dura. [...] O materialismo recusa, portanto, todos os valores de permanência, tudo o que se agarra à duração" (BERL, Emmanuel. Mort de la morale bourgeoise. Paris: Jean-Jacques Pauvert, 1965: 174). ${ }^{30}$ Mesmo niilismo em Leiris, que exalta a hipótese de uma ruína integral que teria "por último resultado, após ter quebrado o que lhe fosse hostil e estranho e depois destruído a si mesmo [...], apenas ter aniquilado absolutamente tudo" (LEIRIS, Michel de. "Débâcle". In: Documents, dez. 1929, n. 7: 382).
}

* (BATAILLE, Georges. "Matérialisme". In: Documents, jun. 1929, n. 3: 170.)

* (PUECH, Henry-Charles. "Les 'Prisons' de Jean-Baptiste Piranèse". In: Documents, 1930, n. 4: 199.) 
cobri-lo. Habent sua falta libelli. Em se tratando de um jornal, a transposiçáo do aoristo para o imperfeito altera o estatuto textual do objeto. A revista é transformada em documento. Publicar em 1990 um fac-símile das Fliegende Blätter de 1929-1930 assemelhase de mais de uma maneira à exposição de uma obra de arte primitiva em um museu parisiense, seja no Museu do Homem ou no Louvre. Carpe diem. Colham a partir de hoje os jornais de amanhã.

Mas é aos kamikazes, às passantes da vanguarda, aquelas que não ultrapassaram duas estaçôes, que cabe a honra da reimpressão. Elas duraram tão pouco que as recordamos. A reimpressão recupera, à sua revelia, o que não quis sobrevida. Documentos, por exemplo. Colocada, como disse Leiris, sob o signo do impossível, era uma revista que não se destinava a durar. $\mathrm{O}$ contrato ideológico parecia ser uma estética do irrecuperável. Também há em sua reediçáo, fênix à força, algo da mesma natureza que, por exemplo, a transformação de matadouros em parques naturais. Nós os civilizados teríamos gostado tanto de poder ser mortais. Mas perdemos a fé. Isso não matará aquilo. Quem hoje se bateria, como o Hugo de Mãos sujas, pelo direito ao irrecuperável? Ou como a Judith de Giraudoux quando percebe com horror que os prazeres inconfessáveis que Holopherne lhe faz conhecer estâo a ponto de serem transformados em história beata, em lenda edificante. De serem dados como exemplo.

Tradução de João Camillo Pena (UFRJ) e Marcelo Jacques de Moraes (UFRJ)

Denis Hollier é professor de Literatura Francesa da Universidade de Nova York. Publicou e organizou vários livros, entre os quais Michel Leiris: La règle du jeu (Editions de la Pléiade, 2003), A New History of French Literature (General ed. Harvard University Press, 1994), Les Dépossédés: Bataille, Caillois, Leiris, Malraux, Sartre (Éditions de Minuit, 1993), Against Architecture: The Writings of Georges Bataille (MIT Press, 1989), La Prise de la Concorde: Essais sur Georges Bataille (Gallimard, 1989) Politique de la prose: Jean-Paul Sartre et l'an quarante (Gallimard, 1982), Le Collège de Sociologie (1937-1939) (Gallimard 1979, rev. ed. 1995).E-mail:<dh25@nyu.edu>. 